\title{
24. PETROGRAPHY AND GEOCHEMISTRY OF RED SEA DOLOMITE
}

\author{
Peter R. Supko, ${ }^{1}$ Peter Stoffers, ${ }^{2}$ and Tyler B. Coplen ${ }^{3}$
}

\section{INTRODUCTION}

Examination of piston cores and, particularly, sediments collected by the Deep Sea Drilling Project has shown that authigenic dolomite occurs in a wide range of sedimentary associations. While the trace to a small percentage of dolomite often encountered in pelagic carbonate sequences may be a result of authigenesis under "normal" deep-sea conditions, the few studies to date seem to indicate that dolomite is abundant only in sediments presumably formed under conditions other than normal open marine. For example, certain dolomite sequences have been ascribed to magnesium enrichment associated with igneous activity (Bonatti, 1966; Riedel et al., 1961). In other cases dolomites are thought to have formed in association with hypersaline brines. A DSDP core (Site 12) from the African continental margin contained abundant dolomite and palygorskite. Peterson, Edgar, et al. (1970) feel that hypersaline brines, formed in near-shore lagoons, moved down through the deep-water sediment sequence by a process of refluxion. In other cases, hypersalinity is associated with desiccation. Miocene sediment sequences drilled in the Mediterranean contain abundant dolomite associated with halite and anhydrite. Ryan, Hsü, et al. (1973) postulate that these sediments formed during a "salinity crisis." Another compelling association is that of dolomite and inferred reducing conditions noted in cores recovered by DSDP from the African continental margin and the Cariaco Trench of the Caribbean Sea (Hayes, Pimm, et al., 1973; Edgar, Saunders, et al., 1973). Whether organic matter itself is a big factor, or whether hypersalinity associated with environmental extremes in these inferred barred basins is controlling, is still a problem.

Dolomite was found to constitute a significant part of portions of the lithostratigraphic sequences at three sites drilled in the Red Sea. These dolomites were studied petrographically and geochemically to determine their nature, to associate them with the depositional environment as deduced by other means, and to see if they themselves could add to our knowledge of that environment.

\section{LITHOSTRATIGRAPHY}

Sites 225, 227, and 228 were drilled (and continuously cored) in the central Red Sea Main Trough, 225 and 227 being to the east of the Axial Trough and 228 to the west (Figure 1). The same four lithostratigraphic units were recognized at all three sites. These units are fully described

\footnotetext{
${ }^{1}$ Scripps Institution of Oceanography, La Jolla, California.

${ }^{2}$ Laboratorium für Sedimentforschung, Universität Heidelberg, Germany,

${ }^{3}$ Institute of Geophysics and Planetary Physics, University of California, Riverside, California.
}

in the Site Report section of this volume and are further discussed by Stoffers and Ross (this volume). Generalized stratigraphic columns with unit correlations are shown in Figure 2 and unit boundary depths, in terms of both meters subbottom and core numbers, are given in Table 1.

Unit I-This unit is basically a biogenic calcareous ooze with varying admixtures of detrital silt and clay. Nannofossil platelets and foraminifera commonly make up the calcareous fraction, with a significant (10\%-30\%) addition of micarb ${ }^{4}$ which, in the Red Sea, is thought to mostly represent diagenetically altered coccolith material. Dolomite is present as rhombs, from a trace to a maximum of 10 percent. Detrital silt and clay constitute 20 to (rarely) 50 percent of unit I sediment at Sites 225 and 227. At Site 228 the overall detrital contribution is higher, including sands of complex mineralogy as a major constituent, reflecting the proximity of an active Plio-Pleistocene Sudan Delta (see Site 228 chapter).

Unit I sediments are generally well burrowed, but occasional layering is seen as color variations, with the colors being indicative of redox potential. White, brown, and reddish colors indicate generally oxidizing conditions, whereas the darker colors (grays, greens) indicate reducing conditions. Darker layers contain pyrite and more abundant organic matter.

Lithified carbonate layers, sometimes rich in pteropods, occur in the upper sections of unit I at Sites 225 and 227. The cement, which is most often composed of aragonite and sometimes of high magnesium calcite, reflects periods at which these minerals were inorganically precipitated, perhaps in conjunction with eustatic fluctuations of sea level (or tectonic movements of a sill area).

Unit II-Sediments of unit II are basically the same as those of the overlying unit except for a higher terrigenous content. As in unit I, there are light gray and dark gray layers, the latter enriched in pyrite and organic matter.

Unit III-This unit is a dark gray to black semilithified dolomitic silty claystone. Dolomite commonly makes up 20 percent of the total, locally attaining 80 percent. The claystone contains abundant analcite in the clay fraction, 5-10 percent pyrite, and is rich (up to $6 \%$ ) in organic carbon. Millerite (NiS) is also present.

Unit IV-Unit IV is an evaporite sequence of alternating anhydrite and halite. The anhydrite is both of laminar and nodular texture; the halite is light gray to clear. The evaporites are described in detail by Stoffers and Kühn (this volume). Dolomite and pyrite occur in abundance as matrix between anhydrite laminae and nodules and as an important constituent of black claystones which are layered within the evaporite sequence.

\footnotetext{
${ }^{4}$ Micarb is a term used to refer to very fine carbonate particles of uncertain origin.
} 


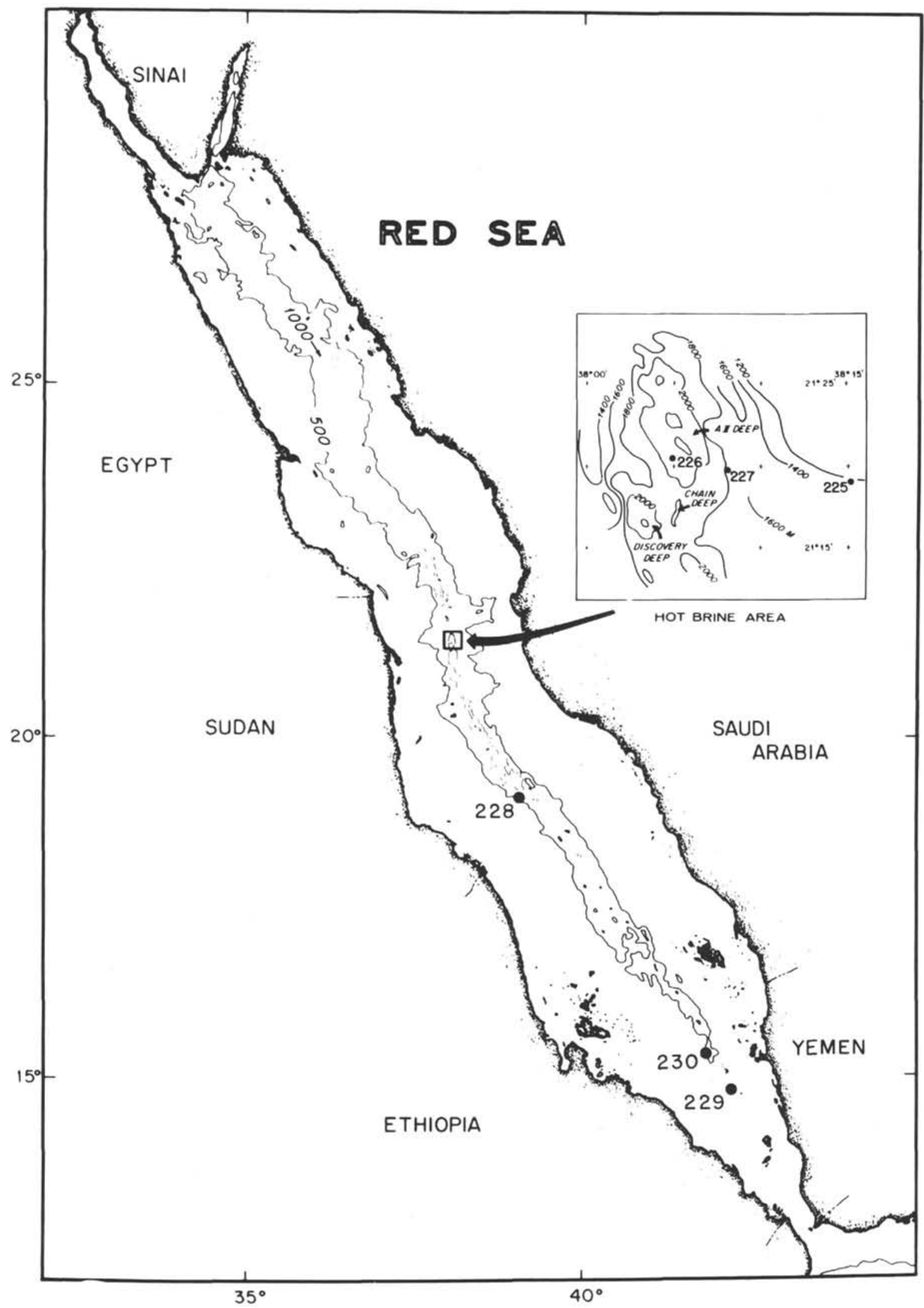

Figure 1. Base map showing the locations of Sites 225, 227, and 228 in the Red Sea. 


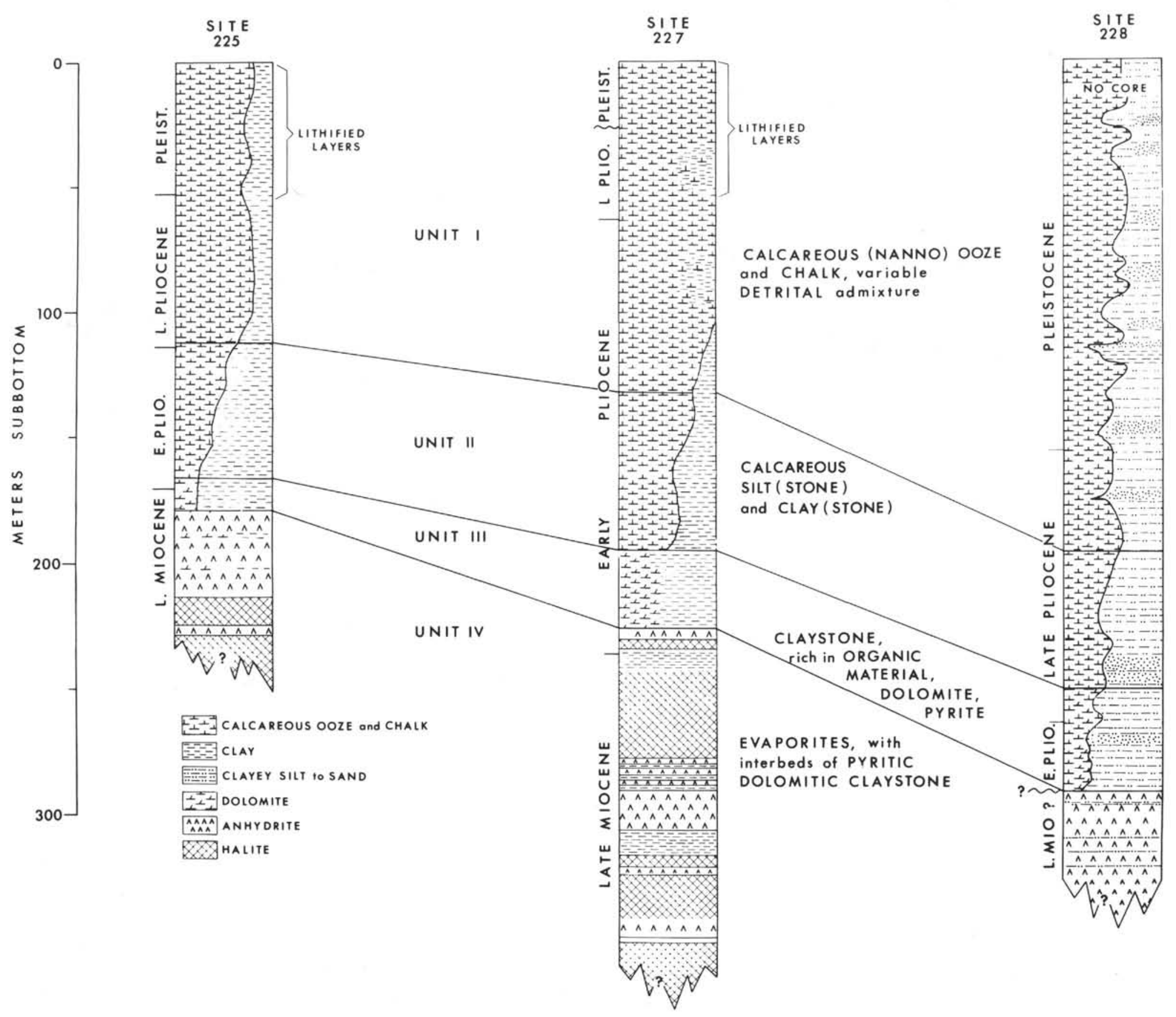


TABLE 1

Unit Boundaries

\begin{tabular}{|c|c|c|c|}
\hline $\begin{array}{l}\text { Sediment } \\
\text { Unit }\end{array}$ & Site 225 & Site 227 & Site 228 \\
\hline Unit I & $\begin{array}{c}0-112 \mathrm{~m} \\
\text { (Cores 1-17) }\end{array}$ & $\begin{array}{c}0-131 \mathrm{~m} \\
\text { (Cores } 1-17 \text { ) }\end{array}$ & $\begin{array}{c}0-195 \mathrm{~m} \\
\text { (Cores 1-24) }\end{array}$ \\
\hline Unit II & $\begin{array}{c}112-167 \mathrm{~m} \\
\text { (Cores } 18-22)\end{array}$ & $\begin{array}{c}131-194 \mathrm{~m} \\
\text { (Cores 18-25) }\end{array}$ & $\begin{array}{c}195-250 \mathrm{~m} \\
\text { (Cores 24-30) }\end{array}$ \\
\hline Unit III & $\begin{array}{l}167-176 \mathrm{~m} \\
\text { (Core 23) }\end{array}$ & $\begin{array}{c}194226 \mathrm{~m} \\
\text { (Cores 26-29) }\end{array}$ & $\begin{array}{c}250-287 \mathrm{~m} \\
\text { (Cores 30-35) }\end{array}$ \\
\hline Unit IV & $\begin{array}{c}176-? \mathrm{~m} \\
(\text { Cores } 24-29)\end{array}$ & $\begin{array}{l}226-? \mathrm{~m} \\
\text { (Cores } 30-45)\end{array}$ & $\begin{array}{c}287-? \mathrm{~m} \\
(\text { Cores } 35-39)\end{array}$ \\
\hline
\end{tabular}

Deposition of the units at the three sites has been roughly synchronous (Figure 2), with evaporite deposition ceasing at the close of the Miocene. Unit III, the dolomitic claystone, was deposited in roughly the Early Pliocene and the biogenic deposit is subsequent to this.

Since units I and II differ only in the relative amount of detrital material admixed, no further distinction will be made between them.

\section{PETROGRAPHY OF DOLOMITES}

Petrographic characteristics of the dolomites were studied in thin section under the petrographic microscope (Peter Stoffers-Heidelberg) and by scanning electron microscopy (Peter R. Supko-Scripps) of slurried and fresh break samples.

In general, dolomites of units I and II are relatively large euhedral rhombs, while those of units II and IV are fine grained and anhedral.

A typical unit I rhomb is seen in Figure 3. It is euhedral and has a crystal edge about $6 \mu$ long and is lying among

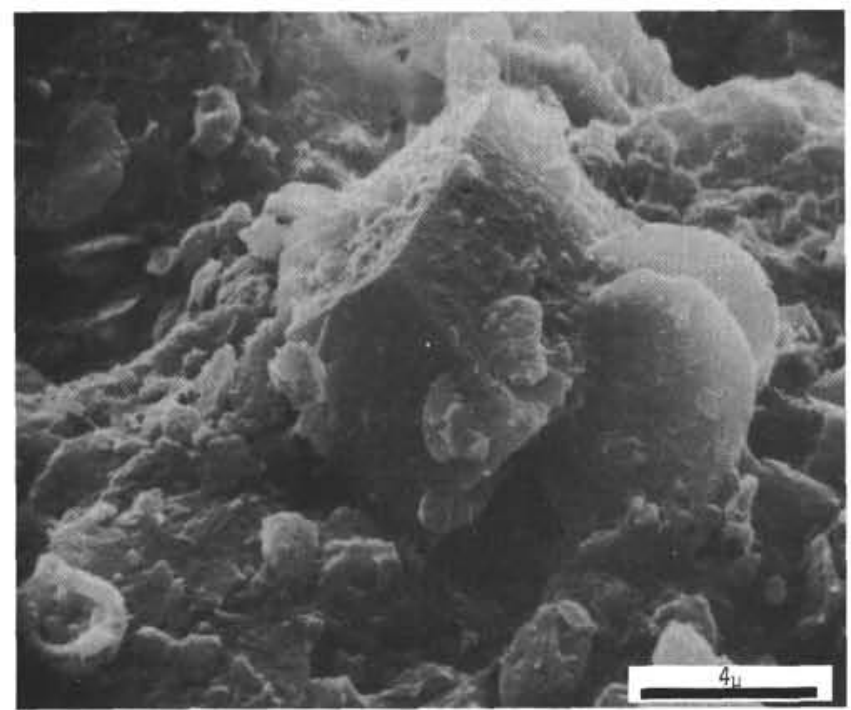

Figure 3. Typical euhedral dolomite rhomb from unit I. Note the two round nanno (?) plates which appear to be recrystallizing onto the rhomb. Slurried sample (SEM) 225-16-2. coccolith plates which, by their relatively poor preservation, appear to be diagenetically altering. Significant are the two round nanno(?) plates attached to the rhomb in the lower right corner of the illustration. This is taken to indicate recrystallization in process. Another such rhomb (same sample) is shown in Figure 4. Note here the

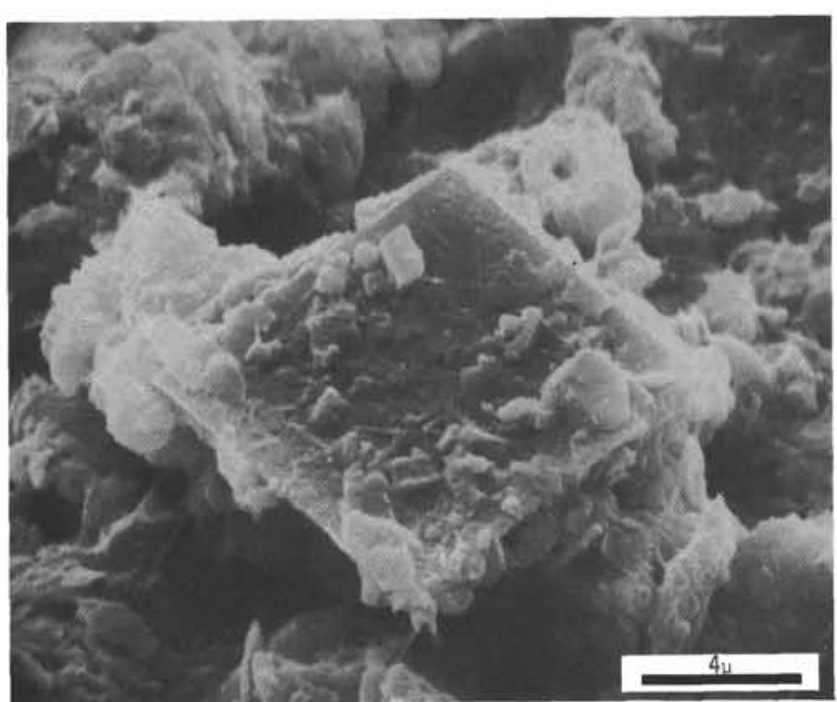

Figure 4. A unit 1 dolomite rhomb lying in a matrix of partially recrystallized coccoliths. Note the sliver-like particles apparently crystallizing onto the top of the rhomb. Slurried sample (SEM) 225-16-2.

recrystallized coccoliths to the upper and lower right of the rhomb and the thin sliver-like particles apparently crystallizing onto the top face of the rhomb.

Dolomites of unit II, the basal and more detrital-rich section of the ooze facies, are similar and, if anything, more perfectly euhedral. Figure 5 shows dolomite euhedra lying in a matrix of clay and recrystallized carbonate. Figure 6 shows a cluster of rhombs with mutually interfering crystal faces, clearly indicating in situ growth. At higher magnification, several crystals exhibit a "spalling" or "peeling off" of crystal faces (Figure 7, note crystals in upper right center and lower left). Even if this occurred during sample preparation (this is a fresh break sample), it might still be indicative of lattice inhomogeneities.

In contrast, SEM observation detected no dolomite euhedra in the half dozen unit III and IV samples studied. Figure 8 depicts a sample from the center of unit III at Site 227. Although X-ray diffraction analysis shows this sample to contain 25 percent dolomite and 75 percent detrital material, repeated scanning showed nothing other than intergrown fine anhedral crystals. An SEM photograph from the center of unit IV at this same site (227) shows a general mosaic of intergrown anhedra (Figure 8). This sample represents a dolomite-pyrite seam between anhydrite nodules.

In unit IV, dolomite is largely associated with organic matter and may occur as scattered anhedral crystals within anhydrite (Figure 9) or may be a replacement of an organic structure, in this case an oncolite (Figure 10, see also photomicrographs in Stoffers and Kuhn, this volume). Note 


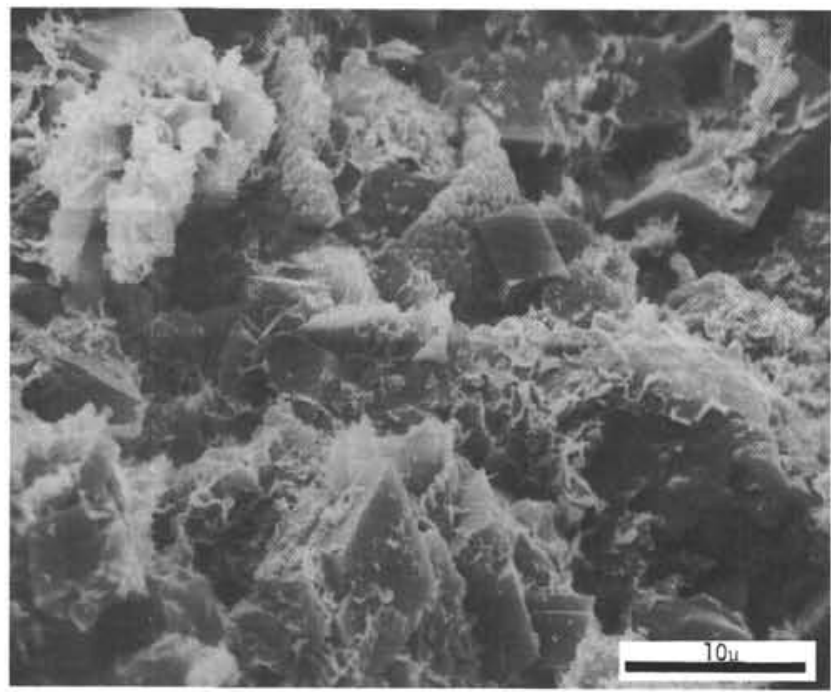

Figure 5. Typical unit II dolomite euhedra lying in a matrix of clay and recrystallized carbonate. Fresh break sample (SEM) 225-21-1.

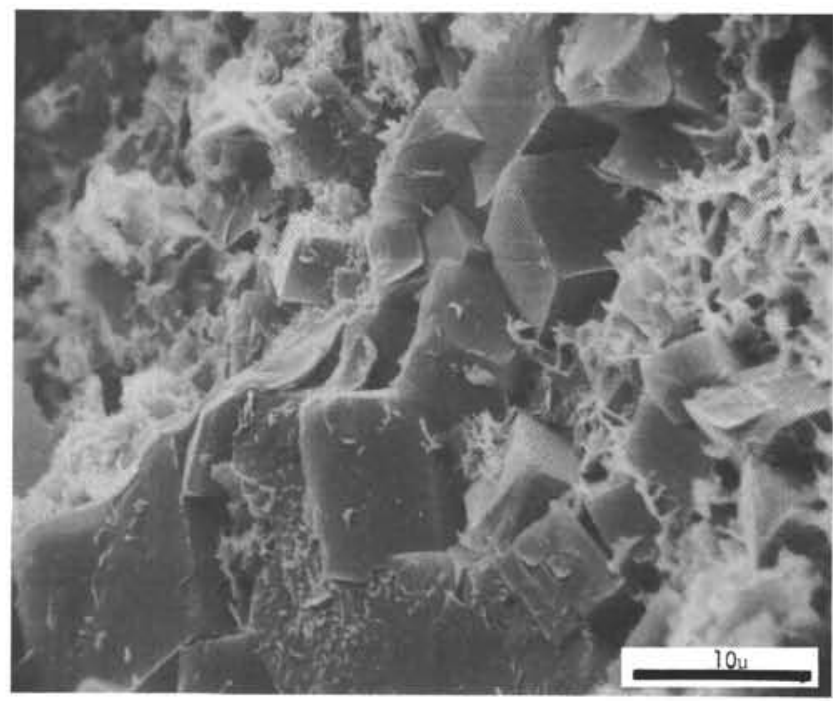

Figure 6. Same sample as Figure 5, here showing a cluster of rhombs with mutually interfering crystal faces.

in Figure 10 the fine, anhedral nature of the dolomite crystals and their darkness due to organic inclusions. The vug in the lower left center is partly filled with anhydrite. Dolomite, associated again with pyrite and organic material, may form matrix separating anhydrite nodules or discrete bands in laminar anhydrite (Figure 11).

\section{GEOCHEMISTRY}

\section{Excess Calcium}

Twenty-nine dolomite samples were analyzed for excess calcium by the X-ray diffraction peak shift method (Goldsmith et al., 1955). Diadochic substitution of $\mathrm{Ca}$ for $\mathrm{Mg}$ in the $\mathrm{Mg}$ cation planes in the dolomite lattice causes shift of the (112) diffraction peak to lower $2 \theta$ values. The degree of peak shift is a function of the amount of excess

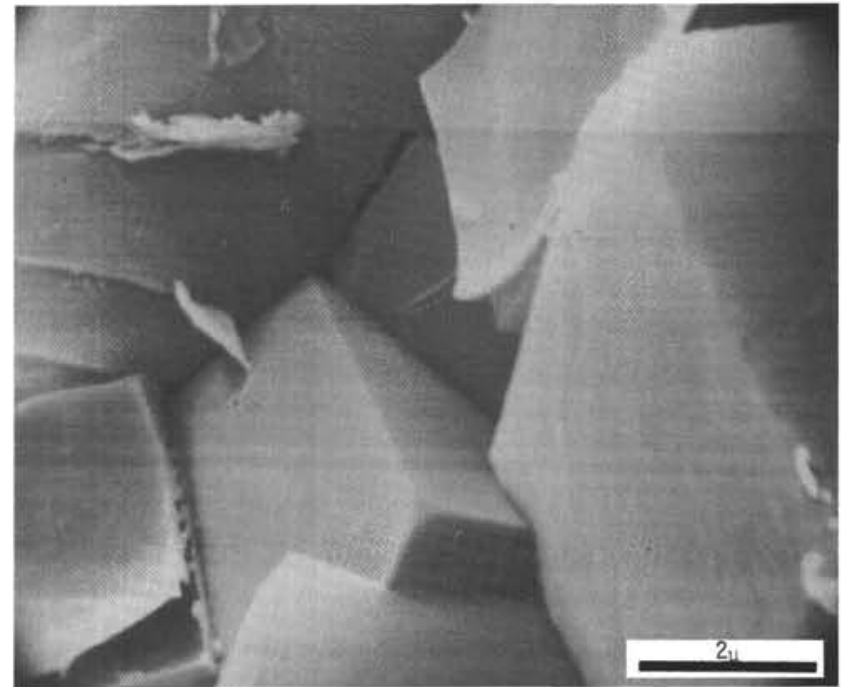

Figure 7. Higher magnification of Figure 6 showing several crystals exhibiting a "spalling" or "peeling off" of crystal faces.

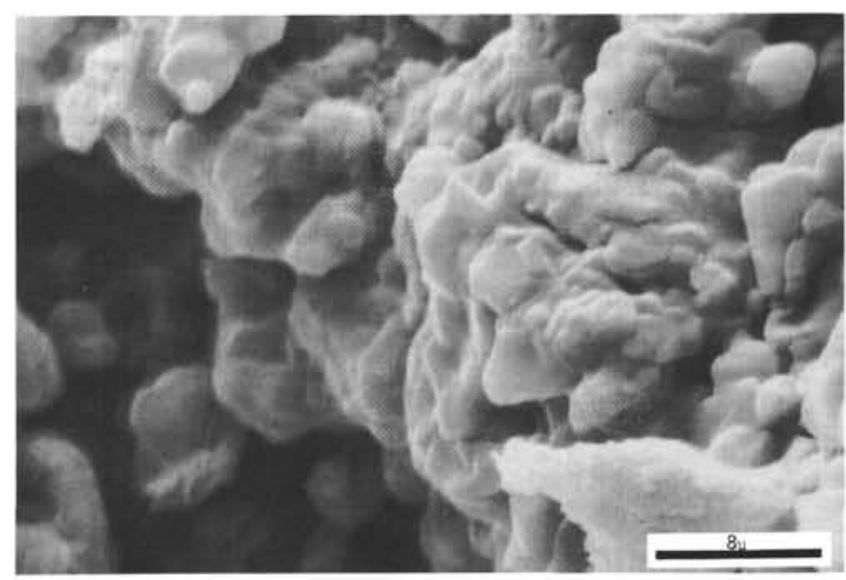

Figure 8. Typical SEM photomicrography of unit III facies. Although $X$-ray diffraction analysis indicates this sample contains 25 percent dolomite, no dolomite euhedra are seen. Fresh break sample (SEM) 227-28-2.

calcium. For example, Figure 12 shows relative (112) peak positions of samples from three cores from different depths subbottom (i.e., different stratigraphic positions) at Site 225. The (112) peak of the sample closest to the top of the section (Core 21) is at a low $2 \theta$ angle, indicating significant excess calcium, whereas the (112) peaks of samples from Cores 25 and 29 are shifted to the higher $2 \theta$ values indicating progressively less excess calcium with depth.

Figure 13 contains 29 data points from the three sites. Excess $\mathrm{mol} \% \mathrm{CaCO}_{3}$ is plotted as a function of depth in meters subbottom. Core numbers and unit boundaries are shown. The trend of decreasing excess calcium in the dolomite lattice with depth in section (i.e., as the evaporite sequence is approached) is apparent at all three sites but is best shown at Site 225. Excess calcium decreases with depth in the section, finally achieving stoichiometric proportions $\left(\mathrm{Ca}_{50} \mathrm{Mg}_{50}\right)$ in the unit IV evaporite sequence. 


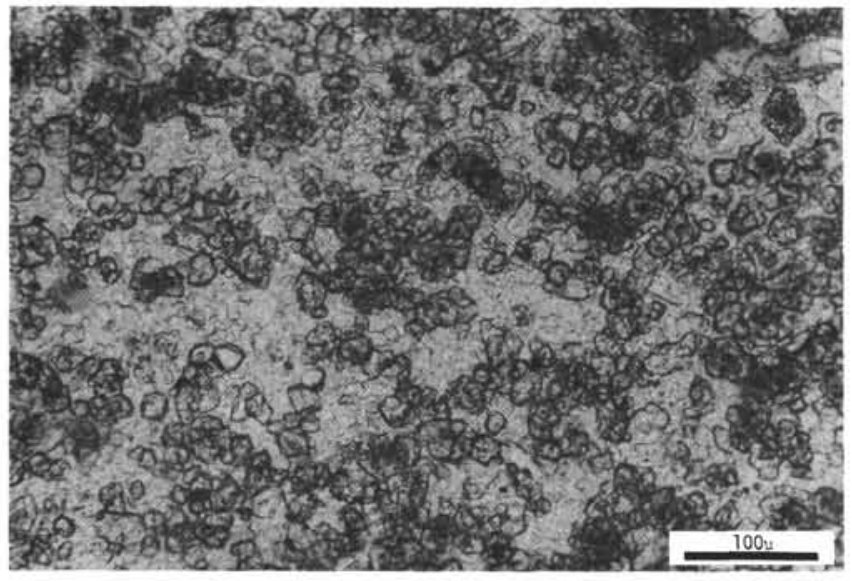

Figure 9. Unit IV dolomite, occurring as scattered anhedral crystals within anhydrite. The dark color is imparted to the dolomite by finely dispersed organic matter. Thin section photomicrography, crossed nicols, 228-36, CC.

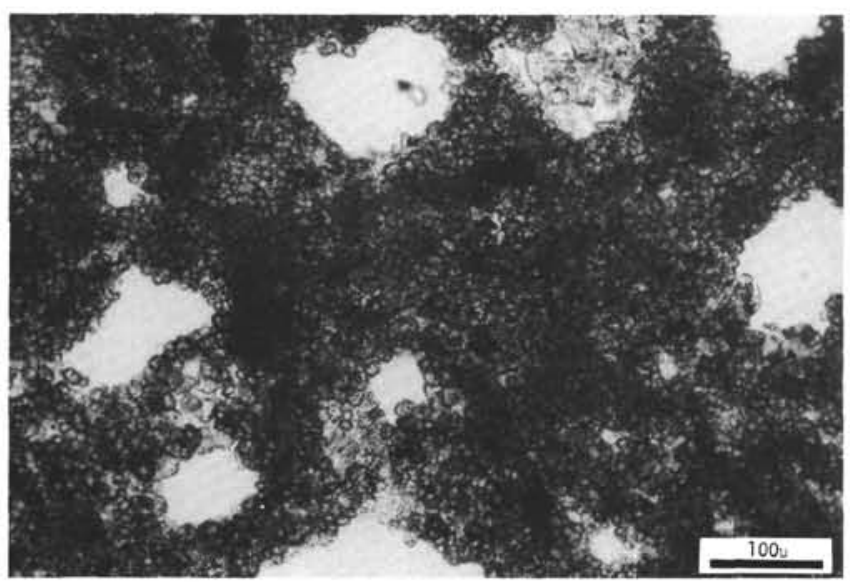

Figure 10. Organic-rich dolomite replacing what appears to be an oncolite. This section photomicrography, plane light, 225-26-1.

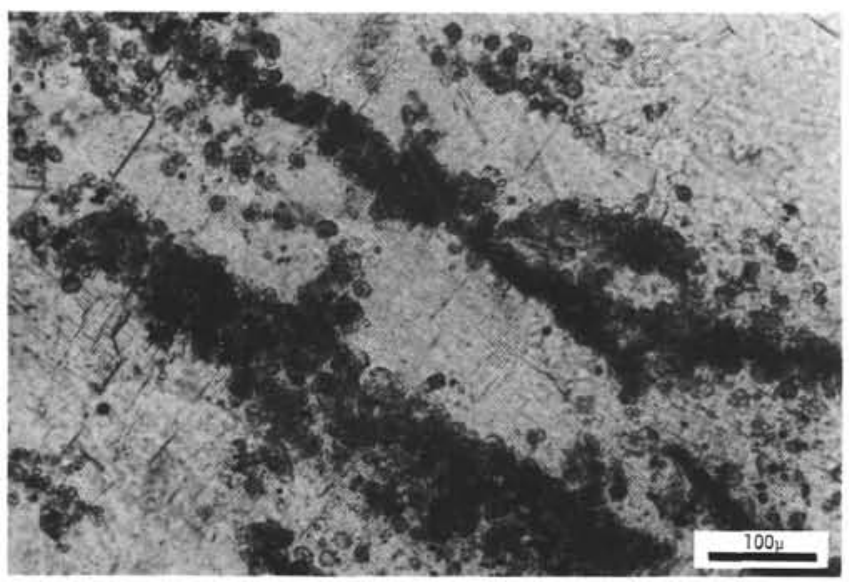

Figure 11. Unit IV dolomite, associated with pyrite and organic material, separating bands of laminar anhydrite. Thin-section photomicrograph, crossed nicols, 227-37, CC.

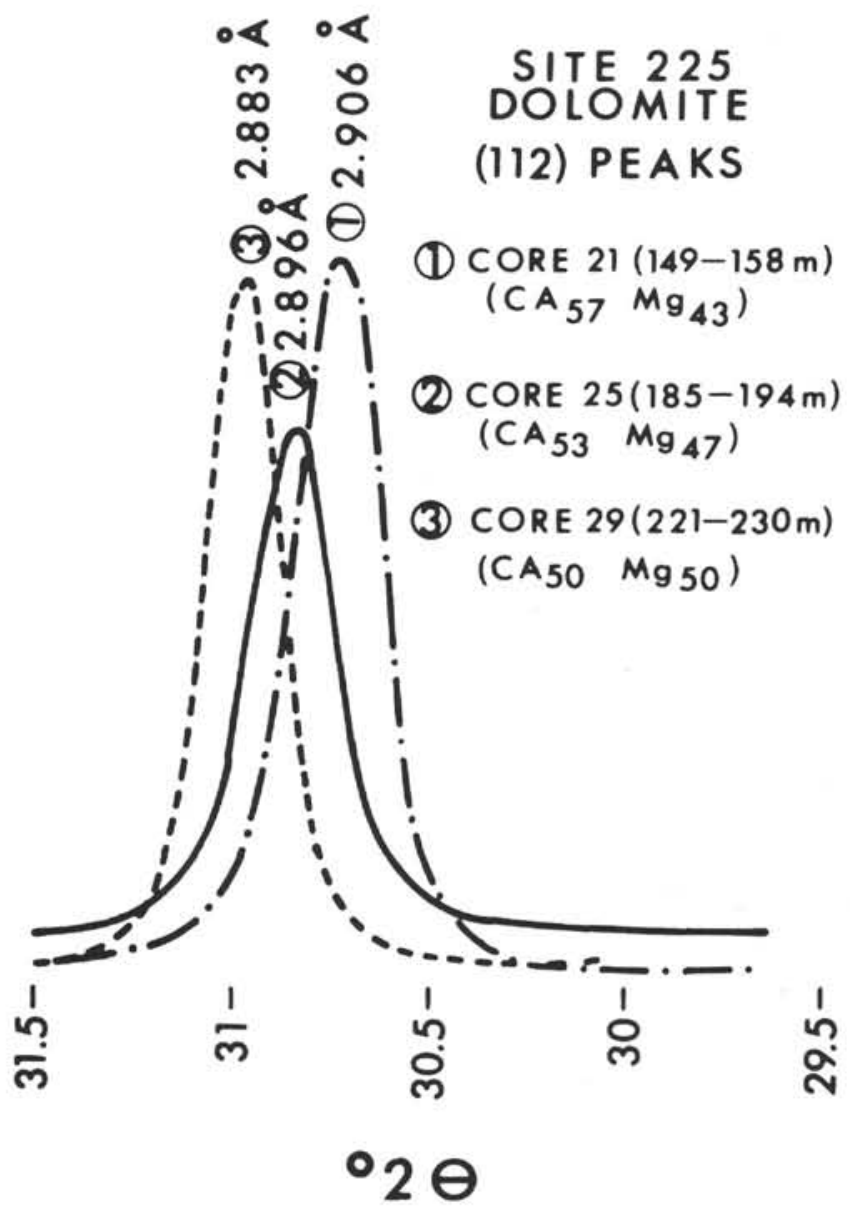

Figure 12. Relative shift of the (112) dolomite peak for three samples at different subbottom depths, Site 225.

\section{Ordering}

As the stoichiometric condition is approached, calcium and magnesium cations become better distributed into discrete basal cation planes. This gives rise to a series of $\mathrm{X}$-ray reflections (ordering peaks) from these planes. Degree of ordering is measured by the relative height of an ordering peak to another peak not directly associated with these alternating cation planes.

There is a slight trend toward increased ordering going from unit III to unit IV, but it is not well enough shown by the relatively few samples run over this portion of the X-ray spectrum to warrant illustration here.

The dolomites in the evaporite sequence are well ordered. Figure 14 shows the relative peak heights of three dolomites associated with the evaporites. The ordering peak at $35.35^{\circ} 2 \theta$, normally absent or just a low bulge in poorly ordered dolomites, is here quite sharp. Measured peak height ratios relative to the nonordering peak at $37.25^{\circ} 2 \theta$ ( $R$ values in Figure 14) are all high when the scale used by Füchtbauer and Goldschmidt (1965) in their study of dolomites of the Zechstein is applied.

Isotopes

Eleven samples were analyzed for $\delta \mathrm{O}^{18}$ and $\delta \mathrm{C}^{13}$ on a double-focusing isotope ratio mass spectrometer (McKinney 

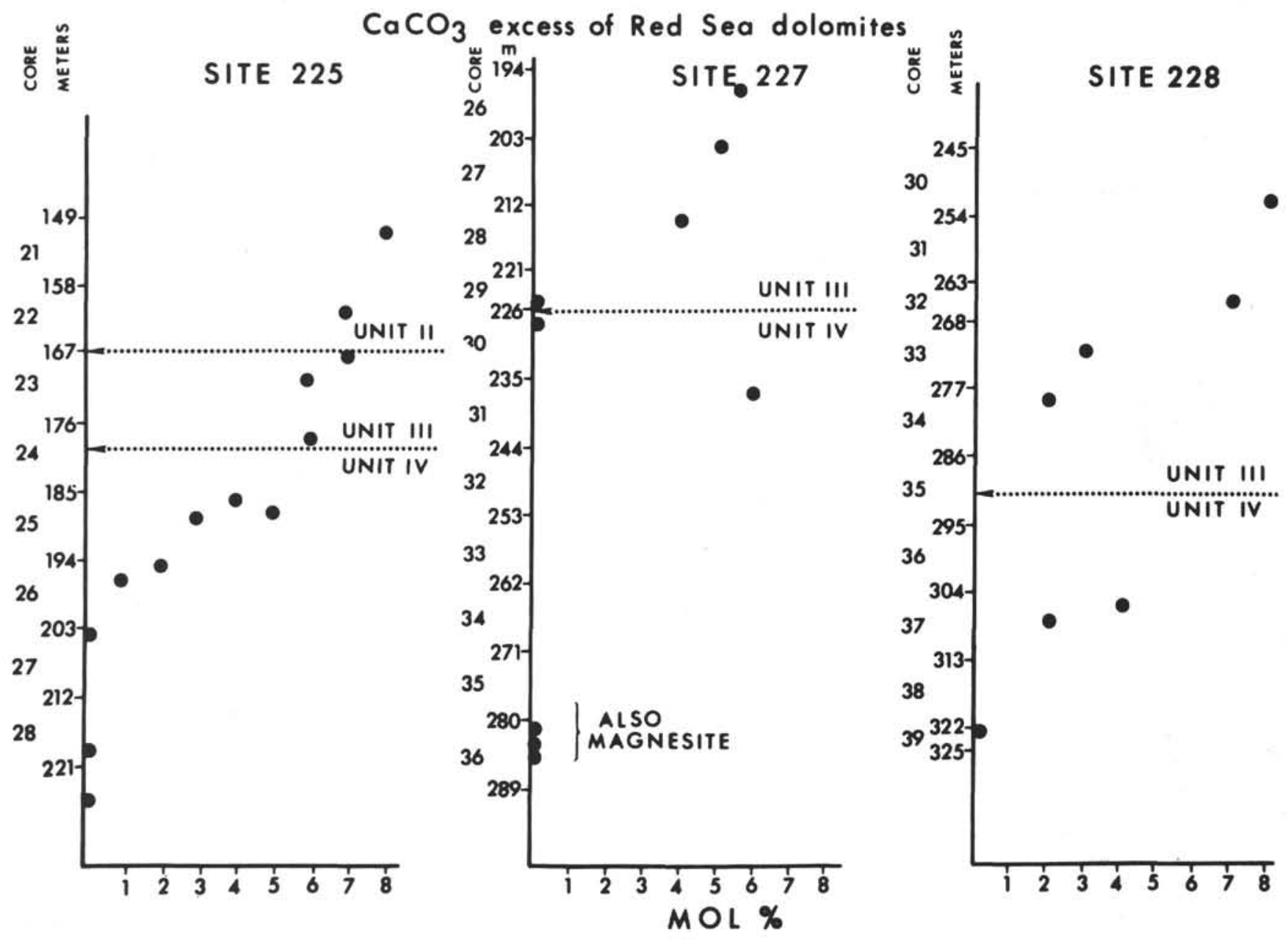

Figure 13. Excess mol\% $\mathrm{CaCO}_{3}$ as a function of depth at Sites 225, 227, and 228 as measured by the peak shift method.

et al., 1950; Coplen, 1973) at the University of California, Riverside laboratory using the method of McCrea (1950). Of these, eight contained both calcite and dolomite, three contained dolomite only. Dolomite was separated from calcite by their differential ractions with 100 percent phosphoric acid-at the end of 1 hour's reaction, the gas extracted was assumed to be primarily calcite derived; the gas derived from 1 and 4 hours was pumped away. The gas derived between 4 hours and 7 days was assumed to be derived primarily from the dolomite. The data are given in Table 2 and are shown as a plot of $\delta \mathrm{O}^{18}$ versus $\delta \mathrm{C}^{13}$ in Figure 15. All data are relative to the Chicago PDB-1 belemnite standard and have been corrected for the phosphoric acid fractionation factor (Sharma and Clayton, 1965),

Stable isotope data must be used with extreme care as supporting data in arguments bearing on dolomitization and carbonate diagenesis because of their dependence on a number of factors, such as: temperature at time of formation, isotopic composition of reservoir water at time of formation, reequilibration with a reservoir different from that at time of formation, precipitation under equilibrium versus nonequilibrium conditions, isotopic composition of precursor sediments, etc. Notwithstanding these many complicated and interrelated factors, most of which are unknown, the Red Sea data allow some insights.

Very striking is the extreme range of isotopic values for $\delta \mathrm{O}^{18}$ and $\delta \mathrm{C}^{13}$ for both calcite and dolomite. The dolomites range in $\delta 018$ from +2.47 to $-6.30 \%$ and in $\delta \mathrm{C}^{13}$ from +2.74 to $-5.69^{\circ} \%$; the calcites range in $\delta \mathrm{O}^{18}$ from +0.78 to $-8.83 \%$ and in $\delta \mathrm{C}^{13}$ from +1.18 to $-7.25 \%$. Also the dolomites from within unit IV themselves have a wide range of $\delta \mathrm{O}^{18}$ values $\left(-0.70^{\circ} \%\right.$ for $225-27-2,-2.89^{\circ} \%$ for $227-36-2,-4.42^{\circ} \%$ or $227-30-1$, and $-6.30 \%$ for $227-29-5$; Table 2, Figure 16). These ranges are interpreted as being environmentally significant and are considered in the Discussion section following.

In addition to the above, the Red Sea isotopic data suggest trends which workers may find helpful in considering the overall problem of utilization of stable isotope data in carbonate studies. We look upon these trends only as guides to needed future research and caution that any statements made here are more food for thought than they are hypothesis. 
ORDERING PEAKS OF RED SEA DOLOMITES
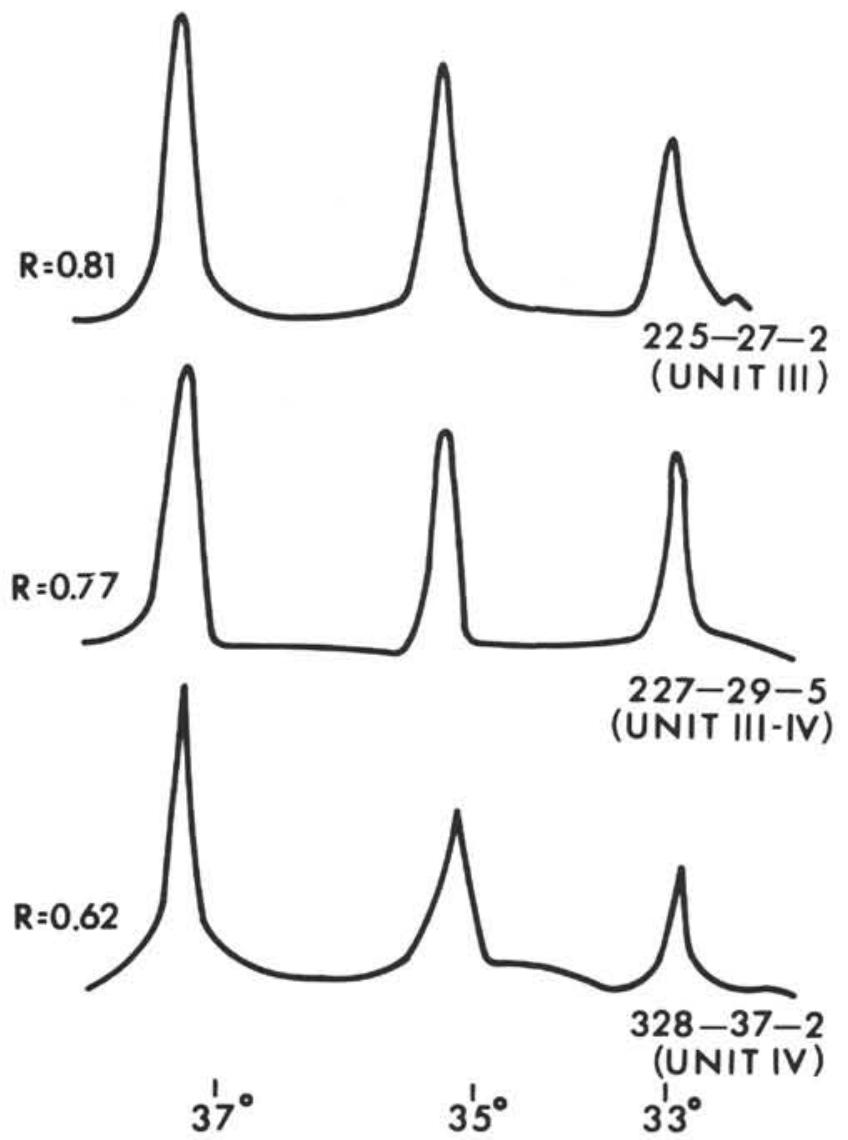

Figure 14. Relative heights of ordering peaks $\left(35.25^{\circ} 2 \theta\right)$ to nonordering peaks $\left(37.25^{\circ} 2 \theta\right)$ of three samples of dolomite asociated with the evaporites. $\mathrm{R}$ values apply to the scale of Füchtbauer and Goldschmidt (1964).

First, there is a general tendency toward more negative oxygen values with depth (Figure 16). This could be explained by one or both of the following:

1) Red Sea carbonates lower in the section formed at progressively high temperatures.

2) Red Sea carbonates lower in the section formed in waters depleted in $\mathrm{O}^{18}$.

The depletion of $\mathrm{O}^{18}$ with depth in carbonate sediment has also been observed by Anderson and Schneidermann (1973) and by Coplen and Schlanger (1973) in studies of recrystallization of deep-sea carbonate oozes. In these deep-sea studies, the cause of this decrease in $\mathrm{O}^{18}$, extending back to Jurassic time, is not well understood.

An interesting observation is the enrichment in $\mathrm{O}^{18}$ of dolomite relative to calcite when both mineral species occur in the same sample..$^{5}$ The $\Delta O^{1}{ }^{8}-\mathrm{C}\left(\delta \mathrm{O}^{18}\right.$ dolomite value minus the $\delta \mathrm{O}^{18}$ calcite value) range 6 is from +0.53 to $+4.69 \%$, averaging $+2.91 \%$. This may represent the

${ }^{5}$ With the exception of the mineral pair in Sample 227-29-5, which shows a $\Delta 0^{18}$ of $-3.5^{\circ} \%$. It is tempting to suspect that the analytical values may have been erroneously recorded in the logging procedure. The sample will be rerun.

${ }^{6}$ Excluding Sample 227-29-5.
TABLE 2

Stable Isotope Analyses of Selected Red Sea Carbonate Samples

\begin{tabular}{|c|c|c|c|c|c|}
\hline Sample & $\begin{array}{c}\text { Sediment } \\
\text { Unit }\end{array}$ & Mineral & $8 \mathrm{C}^{13}$ & $\delta \mathrm{O}^{18}$ & $\Delta \mathrm{O}^{18}$ \\
\hline $\begin{array}{l}227-3-1 \\
27 \mathrm{~cm}\end{array}$ & I & $\begin{array}{l}\text { Calcite } \\
\text { Dolomite }\end{array}$ & $\begin{array}{l}+0.47 \\
+0.85\end{array}$ & $\begin{array}{r}-0.30 \\
+1.38\end{array}$ & +1.68 \\
\hline $\begin{array}{l}227-5-2 \\
120 \mathrm{~cm}\end{array}$ & I & $\begin{array}{l}\text { Calcite } \\
\text { Dolomite }\end{array}$ & $\begin{array}{l}+0.78 \\
+2.74\end{array}$ & $\begin{array}{l}-0.93 \\
-0.40\end{array}$ & +0.53 \\
\hline $\begin{array}{l}225-9-6 \\
132 \mathrm{~cm}\end{array}$ & I & $\begin{array}{l}\text { Calcite } \\
\text { Dolomite }\end{array}$ & $\begin{array}{l}+1.18 \\
+1.75\end{array}$ & $\begin{array}{l}+0.78 \\
+2.47\end{array}$ & +1.69 \\
\hline $\begin{array}{l}228-24-3 \\
28 \mathrm{~cm}\end{array}$ & I-II & $\begin{array}{l}\text { Calcite } \\
\text { Dolomite }\end{array}$ & $\begin{array}{l}-1.72 \\
-2.93\end{array}$ & $\begin{array}{r}-1.99 \\
+1.99\end{array}$ & +3.98 \\
\hline $\begin{array}{l}225-21-1, \\
125 \mathrm{~cm}\end{array}$ & II & $\begin{array}{l}\text { Calcite } \\
\text { Dolomite }\end{array}$ & $\begin{array}{l}-3.16 \\
-5.69\end{array}$ & $\begin{array}{l}-4.12 \\
-0.10\end{array}$ & +4.02 \\
\hline $\begin{array}{l}228-30-5 \\
37 \mathrm{~cm}\end{array}$ & II-III & $\begin{array}{l}\text { Calcite } \\
\text { Dolomite }\end{array}$ & $\begin{array}{l}-2.55 \\
-3.23\end{array}$ & $\begin{array}{l}-4.12 \\
-0.30\end{array}$ & +3.82 \\
\hline 227-29-5, & III-IV & $\begin{array}{l}\text { Calcite } \\
\text { Dolomite }\end{array}$ & $\begin{array}{r}-0.60 \\
+1.20\end{array}$ & $\begin{array}{l}-3.05 \\
-6.30\end{array}$ & -3.25 \\
\hline $\begin{array}{l}227-30-1, \\
135 \mathrm{~cm}\end{array}$ & IV & Dolomite & -5.01 & -4.42 & N/A \\
\hline $\begin{array}{l}227-27-2 \\
60-70 \mathrm{~cm}\end{array}$ & IV & Dolomite & -4.08 & -0.70 & N/A \\
\hline $\begin{array}{l}226-36-2 \\
155 \mathrm{~cm}\end{array}$ & IV & Dolomite & -0.98 & -2.89 & N/A \\
\hline $225-28-1$ & IV & $\begin{array}{l}\text { Calcite } \\
\text { Dolomite }\end{array}$ & $\begin{array}{l}-7.25 \\
-4.04\end{array}$ & $\begin{array}{l}-8.83 \\
-4.14\end{array}$ & +4.69 \\
\hline
\end{tabular}

\section{STABLE ISOTOPES RED SEA CARBONATES}

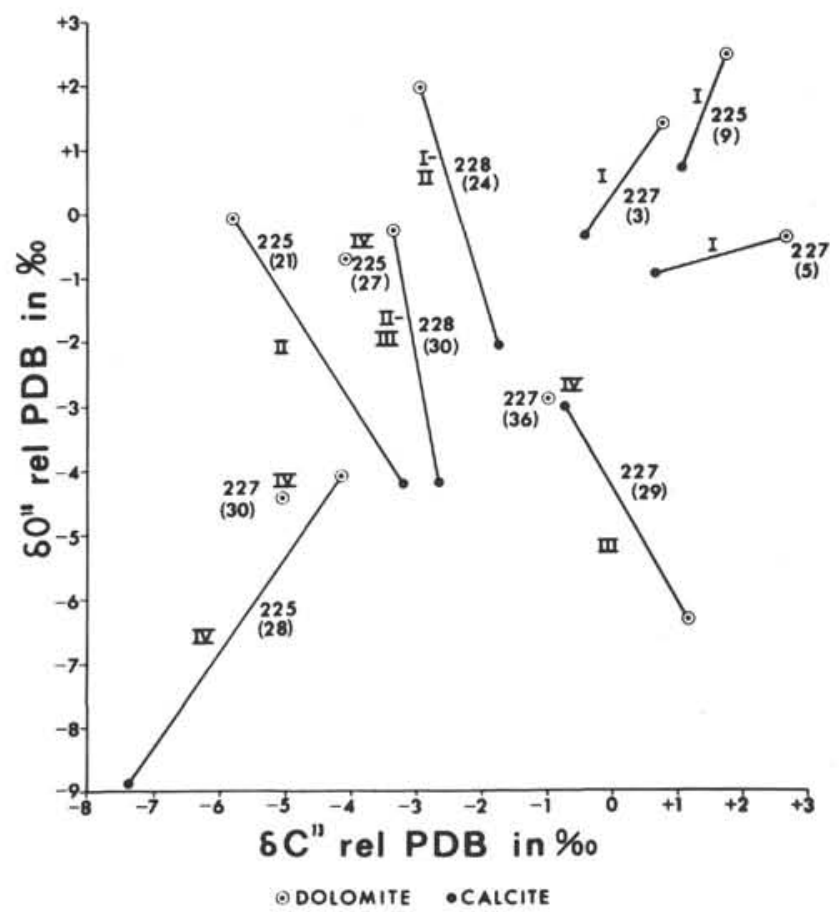

Figure 15. Isotopic ratios of Red Sea dolomites and co-existing calcites, expressed in $\%$ notation relative to the Chicago belemnite standard. 


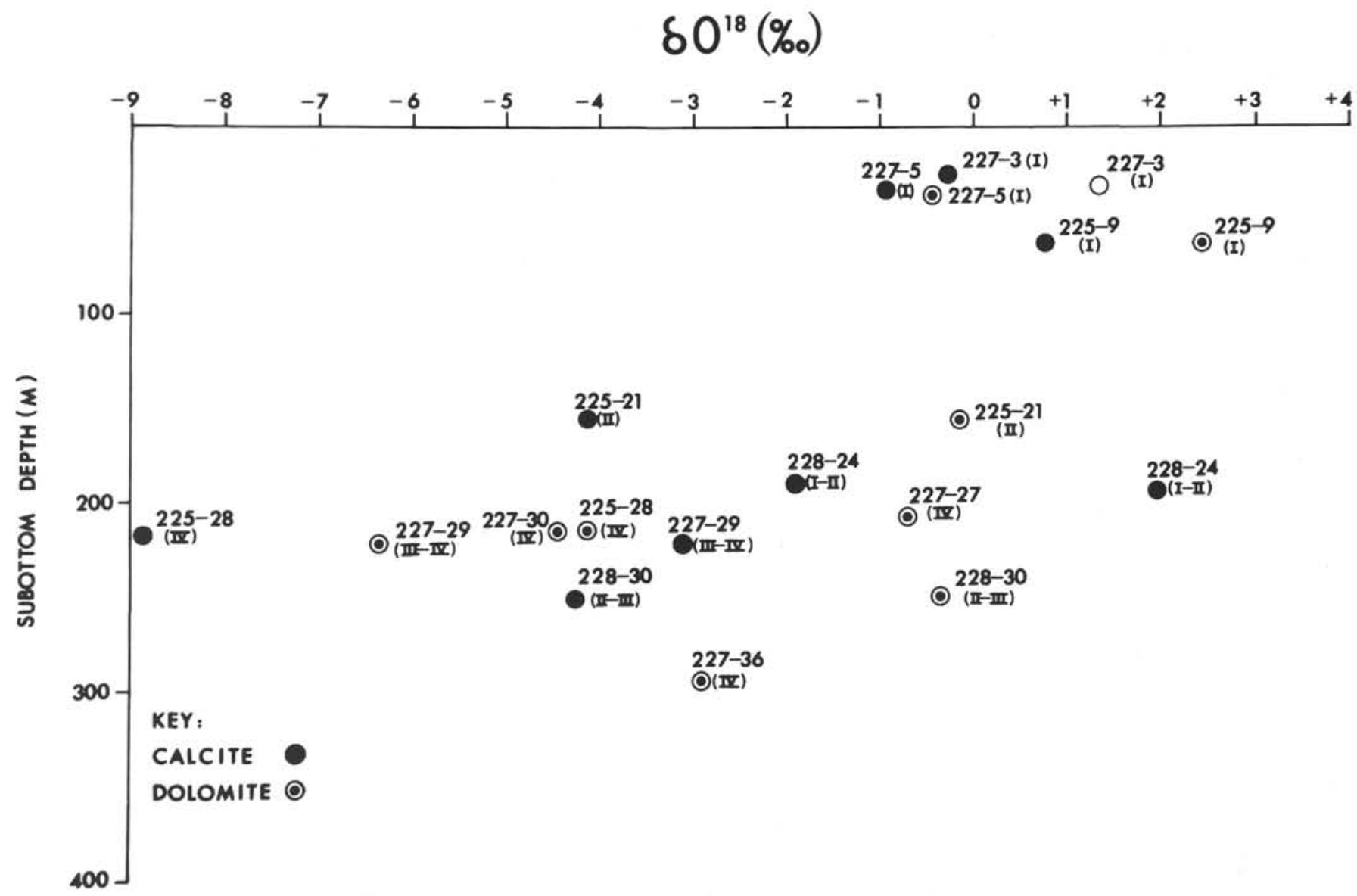

Figure 16. Values of $\delta 0^{18}$ of Red Sea dolomites and calcites plotted versus subbottom depth.

fractionation occurring when the two minerals coprecipitate in chemical equilibrium. Early work (Clayton and Epstein, 1958; Engel et al., 1958) indicated that an equilibrium isotopic fractionation factor between dolomite and calcite should be greater than one, and experiments by Northrop and Clayton (1966) determined it should be about 1.004 to 1.007 at $25^{\circ} \mathrm{C}$ (i.e., approximately $4-7^{\circ} \%$ ) for calcite and stoichiometric dolomite. Certain field studies (e.g., Degens and Epstein, 1964), however, found co-occurring calcite and dolomite with essentially the same $\delta 0^{18}$ values. Clayton et al. (1968) observed that dolomite was enriched by several per mil relative to coexisting calcite in Deep Springs Lake, California. Many authors have since used isotope data variously to support different hypotheses of dolomitization, dependent upon their belief or nonbelief in a fractionation factor. The question has still not been resolved to the satisfaction of isotope geochemists, but recently Fritz and Smith (1970) have shown that calcite and protodolomite (containing several mol \% excess $\left.\mathrm{CaCO}_{3}\right)$ precipitated in the laboratory show a $\Delta \mathrm{O}_{\mathrm{D}}^{18} \cdot \mathrm{C}$ of $3-4^{\circ} \%$.

Another interesting trend indicates the $\Delta \mathrm{O}^{18}$ to increase with depth (Figure 17). This cannot itself be a temperature effect on a fractionation factor, since fractionation should decrease with increasing temperature. Two possibilities may be considered. First, the dolomites deeper in section (units II and IV) more closely approach stoichiometric proportions and are better ordered, as shown in earlier sections. Such are the type of dolomites shown by Northrop and
Clayton (1966) to have higher fractionations (in their case, $4-5 \%$ ) than those of the calcium-rich and poorly ordered protodolomites of Fritz and Smith (1970, $\Delta \mathrm{O}^{18}$ of $3-4 \%$ ) which are more analogous perhaps to the unit I and II Red Sea dolomites. Second, the observed trend with depth may be a result of cross-contamination during sample acidification. In calcite-dolomite mixtures containing well-ordered stoichiometric dolomite, mutual contamination may be minimal (Northrop and Clayton, 1966), but the more calcium-rich the dolomite, the more easily it tends to react with the acid, thus the possibility of contaminating the "calcite" phase exists.

\section{DISCUSSION}

A brief and general outline of the sedimentation history of the Red Sea, as deduced from Leg 23 cores, will help to put the question of the origin of the dolomite into perspective. For detail, see Stoffers and Ross (this volume).

Sedimentary unit IV consists of Late Miocene halite and anhydrite, with local interbeds of pyrite- and dolomite-rich black organic shales. Studies by Leg 23 scientists, and by Leg 13 scientists on correlatible Late Miocene evaporites in the Mediterranean Sea, indicate numerous criteria for shallow-water deposition, including textures, sedimentary structures, presence of stromatolites and oncolites, geochemical evidence, etc. The depositional environment was sabkha-like, for the most part hypersaline, but marked by occasional incursions of fresh continental waters. 


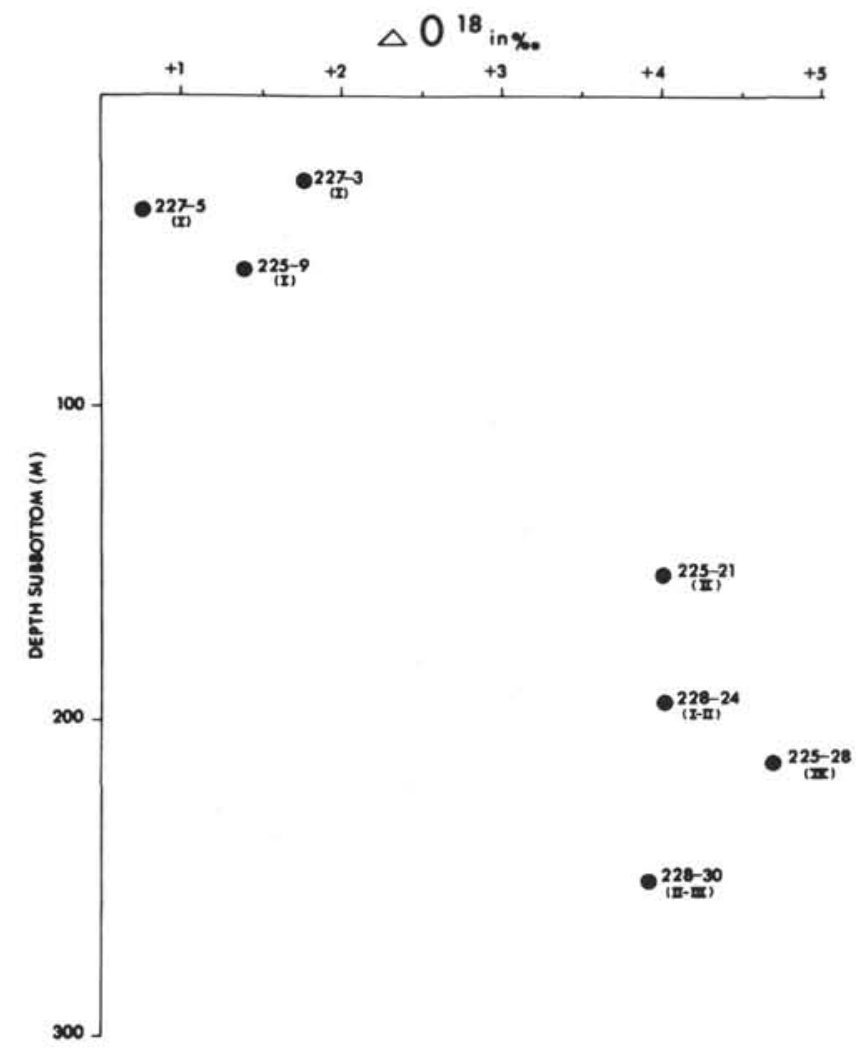

Figure 17. $\Delta 0^{18}$ of Red Sea dolomite-calcite pairs plotted as a function of depth subbottom.

The evaporites are overlain by dolomitic silty claystone, rich in organic matter and pyrite. These deposits were apparently laid down in an Early Pliocene semirestricted basin. These euxinic deposits are overlain by the progressively more open marine deposits of units II and I.

The dolomite associated with the evaporites of unit IV was seen to be very finely crystalline, generally indicative of early diagenetic or primary formation, and, in the samples examined, anhedral. Similar dolomite interbedded in the Messinian evaporites of the Mediterranean is also fine grained, but appears more euhedral under SEM (Nesteroff, 1972). In both the Mediterranean and Red seas, the dolomites are associated with organic matter and pyrite. The Mediterranean samples contain relict biogenic material, nannofossils, and foraminifera, suggesting the dolomites are early diagenetic replacements of marine oozes. The oozes would have been deposited during brief marine incursions between periods of desiccation in a sabkha environment, with attendant deposition of halite and anhydrite. The fine-grained, anhedral dolomites of unit III were probably also formed as penecontemporaneous replacements of marine carbonates under conditions only slightly less environmentally severe.

The question of the triggering mechanism for this early diagenetic dolomitization remains. Fine-grained Holocene dolomite muds supposedly form by early diagenetic replacement of calcium carbonate in a supratidal or sabkha environment under the influence of hypersaline brines of high $\mathrm{Mg} / \mathrm{Ca}$ ratio, this ratio increased via precipitation of calcium sulfate (e.g., Deffeyes et al.,1965; Illing et al.
1965). Close physical and temporal proximity of unit III and IV dolomites to anhydrite and halite indicates that such conditions existed at the time of deposition of these units. Magnesium enrichment is indicated by the presence of authigenic palygorskite (Stoffers and Ross, this volume).

On the other hand, the association of the dolomite with organic matter is also compelling. Recent studies of algal stromatolites (e.g., Gebelein, 1971) indicate certain species of mat-forming algae, through increase in $\mathrm{Mg} / \mathrm{Ca}$ ratio, may foster the precipitation of high magnesian calcite, which in turn may later recrystallize as dolomite. Laminated dolomite-rich layers in the Red Sea cores have been interpreted by Stoffers and Kühn (this volume) as representing stromatolites and oncolites. Davies and Supko (1973) note a relationship between dolomite occurrence and inferred reducing conditions in Deep Sea Drilling cores from Legs 14 and 15. Gieskes (personal communication) notes that, although dolomite at Site 147 (Cariaco Trench, Caribbean Sea) does occur in dark organic layers, it is also very abundant in the alternating gray lutite beds making up the rhythms observed at this site. Since this is a topographically controlled euxinic basin, he cautions that occasional fluctuations of sill depth and/or eustatic sea level might result in hypersalinity. On the other hand, Donnelly (personal communication) notes the association of dolomite with sulfate reduction in the Site 147 (Cariaco Trench) Caribbean Sea cores. Lippmann (1968), based upon analogy with norsethite $\left(\mathrm{Ca} / \mathrm{Mg}\left[\mathrm{CO}_{3}\right]_{2}\right)$, which is similar chemically and structurally to dolomite, states that early diagenetic dolomite should form in the presence of $\mathrm{Mg++}$, given sufficiently high alkalinity. Alkalinity may be raised by bacterial reduction of sulfate. Spotts and Silverman (1966) describe organic dolomite from Point Fermin, California.

The dolomites of units I and II differ from those of units III and IV in being larger and more euhedral. Stoffers and Ross (this volume) have noted that these dolomites are more abundant in sedimentary zones having higher detrital content and conclude that they may therefore represent detrital dolomite. On the other hand, the euhedrality, evidence of incipient recrystallization, and mutually interfering rhombs indicate that at least a portion of the dolomite is authigenic. The controlling factor for dolomitization here is unknown. Although periods of hypersalinity are inferred to have caused precipitation of aragonite and high magnesian calcite in the surface sediment layers of the Red Sea (unit I) (Milliman et al., 1969), dolomite was not found. Whether or not reduction of organic matter may be important here is as yet impossible to say.

The increase in $\mathrm{mol} \% \mathrm{MgCO}_{3}$ and degree of ordering with depth in section (i.e., with proximity to the evaporites) seem to indicate the importance of hypersalinity for dolomite formation. Goldsmith and Graf (1958) have postulated that higher salinities favor the precipitation of well-ordered dolomites. Füchtbauer and Goldschmidt (1965) reported that dolomites formed at higher salinities contain less excess $\mathrm{CaCO}_{3}$ in the lattice, based upon field studies of carbonates from the Lower Tertiary of Libya and Upper Permian and Upper Jurassic of northern Germany. Similarly, Marschner (1968), studying the Triassic Keuper 
Formation of northwest Germany, concludes that the $\mathrm{Mg} / \mathrm{Ca}$ ratio of dolomite is dependent upon degree of hypersalinity at the time of formation and that stoichiometric dolomite is formed only under conditions of hypersalinity. The well-defined trend toward decrease in excess $\mathrm{CaCO}_{3}$ with depth in section (i.e., approach toward evaporites) at these three Red Sea sites seems to confirm the results of these earlier studies.

The wide range of $\delta \mathrm{O}^{18}$ and $\delta \mathrm{C}^{13}$ values for the dolomites of units III and IV (Table 1, Figure 15) is interpreted as indicating conditions of environmental extremes. In a sabkha-like or desert environment, the reservoir supplying oxygen anions for the recrystallization process might at times be enriched in $\mathrm{O}^{18}$ through evaporation, whereas at other times influx of fresh waters might significantly lower the $\mathrm{O}^{18}$ content. Similarly, fresh waters, draining through soil horizons, might occasionally decrease the $\mathrm{C}^{13} / \mathrm{C}^{12}$ ratio below that associated with evaporative conditions.

Fontes et al. (1973) and Lloyd and Hsü (1973) found wide ranges of isotopic values for dolomite samples from the evaporite sequences of the Mediterranean Sea and invoked rapid changes of isotopic composition of a shallow body of brine to explain them. A similar conclusion was reached earlier by Parry et al. (1970) in their studies of West Texas lake carbonates, again formed under conditions of climatic extremes. Deuterium/hydrogen ratios (Friedman and Hardcastle, this volume) of pore waters support meteoric water dilution of Miocene Red Sea brines.

Finally, the general trend toward more negative $\delta \mathrm{O}^{18}$ values for the calcites and dolomites in the Red Sea samples may be a temperature effect. The more negative values with depth in units I and II may reflect fairly recent (and even present) recrystallization at progressively higher temperatures with depth, an effect of geothermal gradient. Assuming this is the case, one can estimate from the points for calcite in units I and II in Figure 16 a slope of $0.01 \%$ per meter. If we assume recrystallization of calcite with an infinite source of water, the "isotope geothermal gradient" would be approximately $4^{\circ} \mathrm{C}$ per 100 meters.

The dolomites of units III and IV, thought to be early diagenetic (penecontemporaneous) cannot be explained by a recrystallization mechanism. The high temperature conditions, as suggested by the very light $\mathrm{O}^{18}$ values of the carbonates, may have been brought about in part by atmospheric (i.e., near surface) conditions, partly due to extreme insolution and partly to adiabatic effect in the presumed deep basin.

Alternatively, the decrease in $\delta \mathrm{O}^{18}$ with depth may not be a temperature factor at all. It may represent a progressively larger degree of incorporation of isotopically light oxygen from bicarbonate produced as a result of sulfate reduction. Or, it may represent a progressive increase in dilution by meteoric water with depth. Much additional work is clearly needed in this field. For a discussion of the complex factors involved, see Lawrence (in press).

\section{CONCLUSIONS}

1. Dolomites within and immediately above the Miocene evaporite series in the Red Sea cores are fine grained and anhedral. They are interpreted as early diagenetic (penecontemporaneous) recrystallization products of original carbonate deposits, probably marine biogenic oozes. They formed in a hypersaline environment, in association with organic matter. Hypersaline brines with high $\mathrm{Mg} / \mathrm{Ca}$ ratios brought about by calcium sulfate precipitation were probably the cause of dolomitization. Alkalinity increase by sulfate-reducing bacteria may have played a role in dolomitization as well.

2. Dolomites of units I and II are larger and more euhedral. While some of the dolomite may be detrital, interfering crystal boundaries, euhedrality, and inferred recrystallization in process indicates that at least some is authigenic. The mechanism is unknown.

3. A trend toward increased ordering and, more strongly, decrease in excess $\mathrm{CaCO}_{3}$ in dolomite as the evaporite sequence is approaced substantiates work by others indicating that increased salinity favors the precipitation of better ordered and more stoichiometric dolomite.

4. Oxygen isotope analyses of carbonates suggest that recrystallization of carbonates has occurred in units I and II. The wide variation in $\mathrm{O}^{18}$ content in units III and IV suggests that the carbonates have not recrystallized or isotopically equilibrated over a scale of tens of meters at a minimum. The enrichment of dolomite in $\mathrm{O} 18$ relative to coexisting calcite by a few per mil is a trend which should be further explored.

\section{ACKNOWLEDGMENTS}

The authors thank Drs. Melvin N. A. Peterson and Joris Gieskes, Scripps Institution of Oceanography, for critically reviewing the manuscript. Since certain suggestions were not followed, errors of omission or commission are solely the authors'. The senior author's research was supported by the U. S. National Science Foundation, Contract C-482. Dr. Stoffers was partially supported by a NATO postdoctoral fellowship.

\section{REFERENCES}

Anderson, T.F. and Schneidermann, N., 1973. Stable isotope relations in pelagic limestones from the central Caribbean, Leg 15. In Edgar, N. T., Saunders, J. B., et al., Initial Reports of the Deep Sea Drilling Project, Volume 15: Washington (U.S. Government Printing Office), p. 795-803.

Bonatti, E., 1966. Deep-sea authigenic calcite and dolomite: Science, v. 153 , p. 54-57.

Clayton, R. N. and Epstein, S., 1958. The relationship between $\mathrm{O}^{18} / \mathrm{O}^{16}$ ratios in coexisting quartz, carbonate and iron oxides from various geological deposits: J. Geol., v. 66, p. 352-373.

Clayton, R. N., Jones, B. F., and Berner, R. A., 1968. Isotope studies of dolomite formation under sedimentary conditions: Geochim. Cosmochim. Acta, v. 32, p. 415-432.

Coplen, T. B., 1973. A double-focusing double-collecting mass spectometer for light stable isotope ratio analysis: Int. J. Mass Spectrom. Ion Phys., v. 11, p. 37-40. 
Coplen, T. B. and Schlanger, S. O., 1973. Oxygen and carbon isotope studies of carbonate sediments from Site 167, Magellan Rise, Leg 17. In Winterer, E. L., Ewing, J. I., et al., Initial Reports of the Deep Sea Drilling Project, Volume 17: Washington (U. S. Government Printing Office), p. 505-510.

Davies, T. A. and Supko, P. R., 1973. Oceanic sediments and their diagenesis: some examples from deep sea drilling: J. Sediment. Petrol., v. 43, p. 381-390.

Deffeyes, K. S., Lucia, F. J., and Weyl, P. K., 1965. Dolomitization of Recent and Plio-Pleistocene sediments by marine evaporite waters on Bonaire, Netherlands Antilles. In Pray, L. C. and Murray, R. C. (Eds.), Dolomitiation and limestone diagenesis: Spec. Pub. No. 13, Soc. Econ. Paleon. Mineral.

Degens, E. T. and Epstein, S., 1964. Oxygen and carbon isotope ratios in coexisting calcites and dolomites from recent and ancient sediments: Geochim. Cosmochim. Acta, v. 28, p. 23-47.

Edgar, N. T., Saunders, J. B., et al., 1973. Initial Reports of the Deep Sea Drilling Project, Volume 15: Washington (U. S. Government Printing Office).

Engel, A. E. J., Clayton, R. N., and Epstein, S., 1958. Variation in isotopic composition of oxygen and carbon in Leadville limestone and its hydrothermal and metamorphic phases: J. Geol., v. 66, p. 374-393.

Fontes, J-Ch., Letolle, R., Nesteroff, W. D., and Ryan, W. B. F., 1973. Oxygen, carbon, sulfur, and hydrogen stable isotopes in carbonate and sulfate mineral phases of Neogene evaporites, sediments, and in interstitial waters, Leg 13. In Ryan, W. B. F., Hsü, K. J., et al., Initial Reports of the Deep Sea Drilling Project, Volume 13: Washington (U.S. Government Printing Office), p. 788-796.

Fritz, P. and Smith, D. G. W., 1970. The isotopic composition of secondary dolomites: Geochim. Cosmochim. Acta, v. 34, p. 1161-1173.

Füchtbauer, H. and Goldschmidt, H., 1965. Beziehungen zwischen calciumgehalt und bildungsbedingungen der dolomite: Geol. Rundschau, v. 55, p. 29-40.

Gebelein, C. D. and Hoffman, P., 1971. Algal origin of dolomite in interlaminated limestone-dolomite sedimentary rocks. In Bricker, O. P. (Ed.), Carbonate cements: Baltimore (Johns Hopkins Press).

Goldsmith, J. R. and Graf, D. L., 1958. Structural and compositional variations in some natural dolomites: J. Geol., v. 66, p. 678-693.

Goldsmith, J. R., Graf, D. L., and Joensuu, O. I., 1955. The occurrence of magnesian calcites in nature: Geochim. Cosmochim. Acta, v. 7, p. 212-230.

Hayes, D. E., Pimm, A. C., et al., 1973. Initial Reports of the Deep Sea Drilling Project, Volume 14: Washington (U. S. Government Printing Office).

Illing, L. V., Wells, A. W., and Taylor, J. C. M., 1965. Penecontemporary dolomite in the Persian Gulf. In Pray, L. C. and Murray, R. C. (Eds.), Dolomitization and limestone diagenesis: Spec. Pub. No. 13, Soc. Econ. Paleon. Mineral.

Lawrence, J. F., in press. Interstitial water studies, Leg 15, stable oxygen and carbon isotope variations in water, carbonates, and silicates from the Venezuela Basin (Site 149) and the Aves Rise (Site 148). In Heezen, B. C., MacGregor, I.G., et al., Initial Reports of the Deep Sea Drilling Project, Volume 20: Washington (U. S. Government Printing Office).

Lippmann, F., 1968. Syntheses of $\mathrm{CaMg}\left(\mathrm{CO}_{3}\right)_{2}$ (Norsethite) at $20^{\circ} \mathrm{C}$ and the formation of dolomite in sediments. In Müller, G. and Friedman, G. M. (Eds.), Carbonate sedimentology in central Europe: New York (SpringerVerlag), p. 33-38.

Lloyd, R. M. and Hsii, K. J., 1973. Preliminary isotopic investigations of samples from deep-sea drilling in the Mediterranean Sea, Leg 13. In Ryan, W. B. F., Hsü, K. J., et al., Initial Reports of the Deep Sea Drilling Project, Volume 13: Washington (U. S. Government Printing Office), p. 783-788.

Marschner, H., 1968. Ca-Mg distribution in carbonates from the Lower Keuper in NW Germany. In Müller, G. and Friedman, G. M. (Eds.), Carbonate sedimentology in central Europe: New York (Springer-Verlag), p. 33-38.

McCrea, J. M., 1950. The isotopic chemistry of carbonates and a paleotemperature scale. J. Chem. Phys., v, 18, p. 849.

McKinney, C. R., McCrea, J. M., Epstein, S., Allen, H. A., and Urey, H. C., 1950. Improvements in mass spectrometers for the measurement of small differences in isotope abundance ratios: Rev. Sci. Inst., v. 21, p. 724.

Milliman, J. D., Ross, D. A., and Ku, T. L., 1969. Precipitation and lithification of deep-sea carbonates in the Red Sea: J. Sediment. Petrol., v. 39, p. 724-736.

Nesteroff, W. D., 1973. Mineralogy, petrogrpahy, distribution, and origin of the Messinian Mediterranean evaporites, Leg 13. In Ryan, W. B. F., Hsü, K. J., et al., Initial Reports of the Deep Sea Drilling Project, Volume 13: Washington (U.S. Government Printing Office), p. 673-695.

Northrop, D. A. and Clayton, R. N., 1966. Oxygen isotope fractionations in systems containing dolomite: J. Geol., v. 74, p. 174-196.

Parry, W. T., Reeves, C. C., Jr., and Leach, J. W., 1970. Oxygen and carbon isotopic composition of West Texas lake carbonates: Geochim. Cosmochim. Acta, v. 34, p. 825-830.

Peterson, M. N. A., Edgar, N. T., et al., 1970. Initial Reports of the Deep Sea Drilling Project, Volume 2: Washington (U. S. Government Printing Office).

Riedel, W. R., Ladd, H. S., Tracey, J. I., Jr., and Bramlette, M. N., 1961. Preliminary drilling phase of the Mohole Project II: Summary of coring operations: Am. Assoc. Petrol. Geol. Bull., v. 45, p. 1793-1798.

Ryan, W. B. F., Hsu, K. H., et al., 1973. Initial Reports of the Deep Sea Drilling Project, Volume 13: Washington (U.S. Government Printing Office).

Sharma, T. and Clayton, R. N., 1965. Measurement of $\mathrm{O}^{18} / \mathrm{O}^{16}$ ratios of total oxygen from carbonates. Geochim. Cosmochim. Acta, v. 29, p. 1347.

Spotts, J. H. and Silverman, S. R., 1966. Organic dolomite from Point Fermin, California: Am. Mineralogist, v. 51, p. 1144-1155. 